ROCZNIKI HUMANISTYCZNE

Tom LXVIII, zeszyt 2 - 2020

DOI: http://dx.doi.org/10.18290/rh20682-5

\title{
OKRUCIEŃSTWA WOJNY CZY PRZEJAW RASIZMU? PRZYPADKI ZNĘCANIA SIĘ NAD JEŃCAMI Z U.S. COLORED TROOPS (USCT) NA WSCHODNIM TEATRZE DZIAŁAŃ WOJENNYCH WOJNY SECESYJNEJ ${ }^{1}-$ WYBRANE PRZYKŁADY $^{2}$
}

Wojna secesyjna nie bez powodu jest uważana za przełomowy konflikt w historii USA. Jednym $\mathrm{z}$ takich powodów jest masowy udział Afroamerykanów, którzy po raz pierwszy od czasów wojny o niepodległość Stanów Zjednoczonych mogli służyć w armii (łącznie ok. 180 tys.). Choć wiele oddziałów U.S. Colored Troops nie było jednostkami frontowymi, to jednak część „kolorowych oddziałów” brała czynny udział w operacjach wojskowych. Konsekwencją tego faktu było zaistnienie kwestii czarnoskórych jeńców. Tu pojawia się pierwsza trudność, a mianowicie problem określenia statusu prawnego czarnych żołnierzy, co w bezpośredni sposób przekładało

Dr Piotr Derengowski - Uniwersytet Gdański, Instytut Historii, Zakład Historii Najnowszej Powszechnej; adres do koresponencji — e-mail: piotr.derengowski@ug.edu.pl; ORCID: https://orcid.org/0000-0002-4414-0545.

${ }^{1}$ Wprawdzie formalnie wschodni teatr działań wojennych obejmował obszar Wirginii, Marylandu, Dystryktu Kolumbii i Pensylwanii, a w 1865 r. także obszar Karoliny Południowej i Północnej, jednak na potrzeby tego wschodni teatr działań wojennych potraktowałem bardziej jako określenie geograficzne niż stricte wojskowe, stąd też do wschodniego teatru działań zaliczyłem zarówno Plymouth (Karolina Północna) jak i Olustee (Floryda).

${ }^{2}$ Niniejszy artykuł stanowi część wystąpienia pt. Przypadki znęcania się nad jeńcami z U.S. Colored Troops (USCT) w okresie wojny secesyjnej - okrucieństwa wojny czy przejaw rasizmu?, prezentowanego na konferencji „W niewoli - doświadczenie jenieckie, regulacje prawne, otoczenie społeczne na przestrzeni wieków" (Niepołomice 2017). Pozostałe dwie części (Status prawny Afroamerykanów i ochrona prawna żolnierzy kolorowych w czasie wojny secesyjnej (1861-1865) oraz Okrucieństwa wojny czy przejaw rasizmu? Przypadki znęcania się nad jeńcami z U. S. Colored Troops (USCT) na zachodnim teatrze działań wojennych wojny secesyjnej - wybrane przyktady) oczekują na druk w „Colloquium” - czasopiśmie Wydziału Nauk Humanistycznych i Społecznych Akademii Marynarki Wojennej w Gdyni. 
się na stosunek obu walczących stron do sprawy ich ewentualnej wymiany, a w przypadku Konfederacji - także na sposób traktowania przebywających w niewoli. Oczywiście w tym wypadku warunkiem koniecznym było wzięcie ich do niewoli przez oddziały Południa. Niestety znacznie częściej zdarzały się przypadki znęcania się czy wręcz bestialskiego mordowania jeńców z U.S. Colored Troops (np. Olustee - 20 lutego 1864 r.; Fort Pillow - 12 kwietnia 1864 r.; Poison Spring - 18 kwietnia 1864 r.; Plymouth - 20 kwietnia 1864 r.; itp.). I tu pojawia się kolejna kwestia. Czy takie zachowanie żołnierzy konfederackich mieściło się $\mathrm{w}$ szeroko pojętych okrucieństwach wojny, rozumianych jako chęć wzięcia odwetu na oddziałach wroga, który plądruje ojczystą ziemię, chęć pomszczenia bliskich lub przyjaciół, którzy zginęli od kul przeciwnika itd. Czy jest to problem głębszy, mający swoje uwarunkowania w kulturze Południa, którego podstawą ideową było istnienie tzw. demokracji panów (Herrenvolk democracy), głęboko zakorzenione przekonanie o wyższości rasy białej nad czarną (nieobce także na Północy), które znalazło swoje odzwierciedlenie nie tylko w przemowach polityków Południa, a później Skonfederowanych Stanów Ameryki, ale także w konstytucji tego kraju.

W niniejszym artykule chciałbym przedstawić bitwy, w których żołnierze kolorowi stali się celem okrutnego traktowania ze strony Południowców. Oczywiście nie jest to pełna lista miejsc, w których doszło do znęcania się nad czarnoskórymi. Wybrane przeze mnie starcia należą jednak do najbardziej znanych i jednocześnie chyba najbardziej drastycznych przykładów łamania prawa wojennego na wschodnim teatrze działań wojennych w czasie wojny secesyjnej. Warto też zauważyć, że we wszystkich opisywanych bitwach to konfederaci byli stroną zwycięską. Niestety w większości przypadków nie da się ustalić ostatecznego przebiegu wypadków. Wprawdzie istnieją różne relacje dotyczące opisywanych wydarzeń, musimy jednak mieć świadomość, że część z nich została zebrana dopiero wiele lat po wojnie. Stąd też ich wiarygodność jest znacznie mniejsza. Niemniej jednak, porównując różne źródła i zestawiając znane nam fakty, można dokonać przynajmniej częściowej rekonstrukcji wydarzeń. Nie jest moim zamiarem przedstawienie pełnego opisu wybranych bitew. Ograniczę się w tej kwestii do zarysowania tła historycznego, które pozwoli umiejscowić opisy znęcania się nad żołnierzami USCT w konkretnym kontekście ${ }^{3}$.

\footnotetext{
${ }^{3}$ Dla ułatwienia lektury tej części artykułu podaję listę stosowanych skrótów w odniesieniu do nazw jednostek wojskowych: komp. - kompania; pp - pułk piechoty; pkaw - pułk kawalerii; bat - bateria; pac - pułk artylerii ciężkiej; pal - pułk artylerii lekkiej.
} 


\section{OLUSTEE (FLORYDA) - 20 LUTEGO 1864}

Bitwa pod Olustee stanowiła kulminację federalnej ekspedycji do wschodniej Florydy, której głównym celem było ponowne przyłączenie tego stanu do Unii na mocy prezydenckiej Proklamacji o Amnestii i Rekonstrukcji z 8 grudnia 1863 r. $^{4}$ Dowództwo nad wyprawą powierzono gen. bryg. Trumanowi B. Seymourowi ${ }^{5}$. Oddziały (ok. 7000 ludzi) zostały zaokrętowane 5 lutego i już następnego dnia ruszyły w kierunku Florydy. 7 lutego ekspedycja dotarła do ujścia rzeki Saint John's, skąd skierowała się w głąb lądu, zajmując Jacksonville. Dwa dni później wojska Unii dotarły do Baldwin, położonego na przecięciu dwóch linii kolejowych (Atlantic\&Gulf Central oraz Florida). Zasadniczo około 14 lutego większość zakładanych celów wyprawy została osiągnięta, przynajmniej w ocenie dowódcy unijnego Departamentu Południa, gen. mjr. Quincy'ego A. Gillmore'a, który w pełni zadowolony $\mathrm{z}$ dotychczasowego przebiegu ekspedycji zalecił wzniesienie umocnień w kontrolowanych przez Unię punktach (m.in. w Jacksonville, Baldwin, Palatka, itd.) i powstrzymanie się od dalszych działań zaczepnych ${ }^{6}$.

\footnotetext{
${ }^{4}$ No. 1. Report of Maj. Gen. Quincy A. Gillmore, U. S. Army, commanding Department of the South, w: The War of the Rebellion: A Compilation of the Official Records of the Union and Confederate Armies (cyt. dalej: OR), seria 1, t. XXXV, cz. 1, Washington 1891, s. 276, 278-279, 294-295 [Q. A. Gillmore do H. W. Hallecka (7 marca 1864); załączniki: A) A. Lincoln do Q. A. Gillmore'a (13 stycznia 1864); B) Q. A. Gillmore do H. W. Hallecka (14 stycznia 1864); C) Q. A. Gillmore do E. M. Stantona (15 stycznia 1864); D) H. W. Halleck do Q. A. Gillmore'a (22 stycznia 1864); E) Q. A. Gillmore do H. W. Hallecka (31 stycznia 1864); Q. A. Gillmore do A. Lincolna (brak daty); General Orders No. 16 (31 stycznia 1864)]; W.A. DoBAK, Freedom by the Sword. The U.S. Colored Troops, 1862-1867, Washington 2011, s. 61-62; N.A. TRudEAu, Like Men of War. Black Troops in the Civil War 1862-1865, Boston-New York-Toronto-London 1998, s. 121-125.

${ }^{5}$ David J. Coles przypuszcza, że gen. Seymour wyprawą na Florydę chciał odzyskać część prestiżu utraconego rok wcześniej podczas nieudanego ataku na Fort Wagner (18 lipca 1863 r.). Część prasy ostro krytykowała wówczas Seymoura nie tylko za klęskę, ale przede wszystkim za zbyt małe zainteresowanie będącymi pod jego rozkazami oddziałami kolorowymi. D.J. CoLES, "Shooting Niggers Sir". Confederate Mistreatment of Union Black Soldiers at the Battle of Olustee, w: Black Flag Over Dixie. Racial Atrocities and Reprisals in the Civil War, red. G.J.W. Urwin, Carbondale 2004, s. 68-69; E.J. WARNER, Generals in Blue. Lives of the Union Commanders, Baton Rouge 1964, s. 432-433.

${ }^{6}$ No. 1. Report of Maj. Gen. Quincy A. Gillmore, U. S. Army..., w: OR, seria 1, t. XXXV, cz. 1, s. 277, 280-281, 293 [Q. A. Gillmore do H.W. Hallecka (7 marca 1864); załączniki: F) Q.A. Gillmore do T. B. Seymoura (4 lutego 1864); G) Q. A. Gillmore do T. B. Seymoura (5 lutego 1864); H) Q. A. Gillmore do H. W. Hallecka (9 lutego 1864); Q. A. Gillmore do H. W. Hallecka (13 lutego 1864)]; Extracts from a report of Surgeon Ebenezer Swift, U. S. Army, on the operations, expedition and engagement, Olustee, Florida, February 20, 1864, w: Supplement to the Official Records of the Union and Confederate Armies [cyt. dalej: SOR], cz. 1, Reports, t. VI, seria 6, Wilmington 1996, s. 452-453; W.A. DOBAK, Freedom by the Sword, s. 63-65; H.B. HARGRove, Black Union Soldiers in the Civil War, Jefferson-London 2003, s. 165; N.A. TRUDEAU, Like Men of War, s. 129-135.
} 
Jakież było zdziwienie Gillmore’a, kiedy 18 lutego otrzymał wiadomość od Seymoura, informującą o podjęciu ofensywy na zachód w celu zniszczenia mostu kolejowego na rzece Suwanee (ok. $160 \mathrm{~km}$ od Jacksonville). Gillmore natychmiast wysłał na Florydę swojego szefa sztabu, gen. bryg. Johna W. Turnera, z rozkazem wstrzymania działań. Niestety, ze względu na fatalną pogodę i wynikłe stąd opóźnienie, dotarł on do Jacksonville w momencie kiedy trwała już bitwa pod Olustee ${ }^{7}$.

Rankiem owego feralnego dnia (20 lutego 1864 r.) gen. Seymour wyruszył z Barber's Station w kierunku Lake City, formując swoje siły liczące ok. 5-5,5 tys. żołnierzy w trzy brygady. Pierwsza brygada pod dowództwem płk. Josepha Hawleya składała się z 7. pp z Connecticut, 7. pp z New Hampshire oraz 8. pp USCT ${ }^{8}$. Drugą brygadę (płk. William Barton) tworzyły trzy nowojorskie pułki (47., 48. i 115. pp), a trzecią (płk. James Montgomery) dwa czarne regimenty (54. pp z Massachusetts ${ }^{9}$ oraz 1. pp kolorowej z Karoliny Północnej ${ }^{10}$ ). Całość wspierała jeszcze kawaleria i artyleria.

\footnotetext{
${ }^{7}$ Tamże, s. 137; No. 1. Report of Maj. Gen. Quincy A. Gillmore, U. S. Army..., w: OR, seria 1, t. XXXV, cz. 1, s. 277, 284-286 [Q. A. Gillmore do H. W. Hallecka (7 marca 1864 r.); załączniki: P) T. B. Seymour do Q. A. Gillmore'a (17 lutego 1864); Q) Q. A. Gillmore do T. B. Seymoura (18 lutego 1864)]; H.B. HARGROVE, Black Union Soldiers, s. 165.

${ }^{8}$ Jednostka ta została utworzona na przełomie 1863 i 1864 r. w Pensylwanii. Jej rekruci byli to głównie wolni Murzyni z terenów Pensylwanii i Delaware oraz „kontrabanda”. Dowódcą został płk Charles N. Fribley, weteran z 84. pp z Pensylwanii. Regiment nie miał żadnego wcześniejszego doświadczenia bojowego, co więcej - w chwili rozpoczęcia ekspedycji na Florydę nie ukończył nawet szkolenia. S.P. BATES, History of Pennsylvania Volunteers, 1861-5, t. V, Harrisburg 1871, s. 965; D.J. Coles, "Shooting Niggers Sir", s. 69. Zob. też: Record of Events for Eighth United States Colored Infantry, October 1863-June 1865, w: SOR, cz. 2, Record of Events, t. LXXVII, seria 89, Wilmington 1998, s. 410-425.

${ }^{9}$ Jeden z najbardziej znanych regimentów kolorowych z okresu wojny secesyjnej. Utworzona na początku 1863 r. jednostka w znacznej mierze składała się z wolnych Murzynów z Północy. Jej pierwszym dowódcą został Robert Gould Shaw (1837-1863), który zginął podczas nieudanego szturmu na Fort Wagner (18 lipca 1863). W czasie ekspedycji na Florydę dowódcą regimentu był płk Edward N. Hallowell. Historia pułku stała się kanwą hollywoodzkiej superprodukcji pt. Glory („Chwała”) w reżyserii Edwarda Zwicka (1989). D.J. ColeS, “Shooting Niggers Sir”, s. 69-70. Szerzej o 54. pp z Massachusetts zob. P. BuRCHARD, One Gallant Rush. Robert Gould Shaw and His Brave Black Regiment, New York 1989; R. DunCAN, Where Death and Glory Meet. Colonel Robert Gould Shaw and the 54th Massachusetts Infantry, Athens 1999; L.F. EMILIO, History of the Fifty-Fourth Regiment of Massachusetts Infantry, 1863-1865, Boston 1891; Record of Events for Fifty-fourth Massachusetts Colored Infantry, March 1863-June 1865, w: SOR, cz. 2, t. LXXVIII, seria 90, Wilmington 1998, s. 230-253.

${ }^{10}$ Regiment został sformowany latem 1863 r. głównie z byłych niewolników z Wirginii i obu Karolin. Dowódcą jednostki został płk James Beecher, brat słynnej Harriet Beecher Stowe, autorki Chaty wuja Toma. W czasie ekspedycji na Florydę komendę pułku sprawował jednak ppłk William Reed, Beecher pełnił wówczas służbę rekrutacyjną na Północy. Podobnie jak 8. pp USCT regiment nie miał praktycznie żadnego doświadczenia bojowego. D. J. CoLES, "Shooting
} 
Około południa idąca na czele jazda natknęła się na konfederackie pikiety. Wkrótce została wsparta kilkoma kompaniami 7. pp z Connecticut i wyparła Południowców. Idąc w ślad za uchodzącym wrogiem, federalni po chwili natknęli się na ustawioną w szyku bojowym konfederacką brygadę Alfreda $\mathrm{H}$. Colquitta. Wobec zdecydowanej przewagi rebeliantów pułkownik Hawley zmuszony był wycofać 7. pp z Connecticut i podciągnąc pozostałe dwa regimenty swojej brygady, które formowały linię bojową już pod ostrzałem wroga. 7. pp z New Hampshire nie zdołał przeprowadzić tego manewru, załamał się i rzucił do ucieczki. Chwilowo jedyną jednostką Unii na polu bitwy był 8. pp USCT i to właśnie na nim skupiła się cała uwaga Południowców. Brak doświadczenia i odpowiedniego szkolenia zbierał teraz krwawe żniwo. Jak wspominał por. Oliver W. Norton, „choć [żołnierze] potrafili stać i dać się zabić, nie byli w stanie zabić kryjącego się wroga"11. Pułkownik Fribley, widząc, co się dzieje, nakazał powolny odwrót. Wkrótce sam został śmiertelnie ranny. Około 16.30 8. pp USCT opuścił pole bitwy, tracąc łącznie 310 żołnierzy. Ciężar walk spoczął wówczas na nowojorskiej brygadzie Bartona, która bezskutecznie starała się powstrzymać napierających coraz silniej konfederatów, ponosząc przy tym spore straty. Wtedy też na polu bitwy pojawiła się brygada Montgomery'ego. Generał Seymour, widząc, że nie da się już odwrócić losów starcia, nakazał odwrót pod osłoną 54. pp z Massachusetts i 1. pp kolorowej z Karoliny Północnej, wspieranych przez kawalerię i 7. pp z Connecticut. Według raportu porucznika M.B. Granta federalni, wycofując się, zabrali z sobą tylko białych, pozostawiając swoich zabitych i rannych czarnych żołnierzy bez opieki ${ }^{12}$. Zgoła inną wersję przedstawił sierżant sztabowy Rufus S. Jones z 8. pp USCT, który twierdził, że dzięki chirurgowi A.P. Heicholdowi ranni żołnierze kolorowi mieli pierwszeństwo przy załadunku na ambulanse ${ }^{13}$. Troska doktora Heicholda o los czarnoskórych żołnierzy, którzy wpadną w ręce konfederatów, była jak najbardziej na miejscu, faktem jednak pozostaje, że mimo jego wysiłków wycofujące się do Barber's Station wojska Unii pozostawiły za sobą na polu bitwy znaczną liczbę rannych i zaginionych ${ }^{14}$.

Niggers Sir”, s. 70. Zob. też: Record of Events for Thirty-fifth United States Colored Infantry (formerly First North Carolina Colored Infantry), June 1863-June 1865, w: SOR, p. II, vol. LXXVII, ser. 89, s. 762-779.

${ }^{11}$ Cyt. za: N.A. Trudeau, Like Men of War, s. 142.

${ }^{12}$ No. 18. Report of Lieut. M. B. Grant, C. S. Engineers, of engagement at Olustee, w: OR, seria 1, t. XXXV, cz. 1, s. 341; D.T. CoRnish, The Sable Arm. Black Troops in the Union Army, 1861-1865, Lawrence 1987, s. 269.

${ }^{13}$ N.A. TRUdEAU, Like Men of War, s. 150.

${ }^{14}$ Straty Unii pod Olustee wyniosły 1861 żołnierzy. Z tej liczby aż 626 przypada na 8. pp 
Afroamerykanie, którzy zostali na pobojowisku, mieli doświadczyć prawdziwych katuszy w najbliższych godzinach i dniach. Zasadniczo nadużycia Południowców możemy podzielić na dwie główne kategorie: 1) traktowanie rannych i schwytanych czarnych w ciągu kilku godzin bezpośrednio po bitwie oraz 2) obchodzenie się z żołnierzami kolorowymi, którzy przetrwali pobitewne znęcanie i zostali wysłani do konfederackich obozów jenieckich. Co ciekawe, większość relacji dotyczących tych zachowań pochodzi od samych rebeliantów ${ }^{15}$.

Wydaje się, że większość działań konfederatów wobec Murzynów nie stanowiła odgórnie sterowanej akcji i była wynikiem oddolnej inicjatywy żołnierzy niższego szczebla. James Jordan z 27. pp z Georgii w liście do żony pisał, że „nasi zabili niektórych [czarnych] po tym, jak wpadli ranni

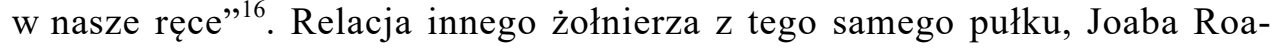
cha, może wskazywać natomiast, że przynajmniej część poczynań Południowców nie była do końca spontaniczna i nosiła znamiona zorganizowanej akcji wymierzonej w Afroamerykanów. „Po walce nasi chłopcy przeszli przez pole bitwy i uderzali w głowy kijami większość rannych czarnych"17. Wygląda na to, że chęć zemsty na żołnierzach kolorowych momentami zaczęła wymykać się spod kontroli. William Penniman z 4. pkaw z Georgii, który przemierzał pole bitwy tuż po jej zakończeniu, wspomina, że było słychać liczne strzały, jak gdyby wciąż prowadzono walkę ogniową. Kiedy natknął się na oficera i zapytał, co się dzieje, w odpowiedzi usłyszał: „Strzelamy [do] czarnuchów, Sir. Starałem się zmusić chłopców do zaprzestania, ale nie jestem w stanie ich kontrolować" ${ }^{18}$. Nie można także wyklu-

USCT (49 zabitych, 188 rannych i 73 zaginionych), 1. pp kolorowej z Karoliny Północnej (22 zabitych, 131 rannych i 77 zaginionych) oraz 54. pp z Massachusetts (13 zabitych, 65 rannych i 8 zaginionych), w tym 158 zaginionych (część z nich bez wątpienia zginęła w trakcie chaotycznej walki, pozostali najprawdopodobniej pozostali ranni na polu bitwy). Tamże, s. 150-152; No. 2. Reports of Brig. Gen. Truman Seymour, U. S. Army, Commanding District of Florida, w: OR, seria 1, t. XXXV, cz. 1, s. 298; Report of Colonel Edward Needles Hallowell, Fifty-fourth Massachusetts, of engagement during the Florida expedition, February 20, 1864, w: SOR, cz. 1, t. VI, seria 6, s. 457-458; Report of Captain James N. Croft, First North Carolina Colored Volunteers (Union), of the engagement at Olustee, Florida, February 20, 1864, w: tamże, s. 458-460; Report of Lieutenant-Colonel Charles Rinaldo Floyd Hopkins, First Florida Battalion, of the Battle of Ocean Pond, Florida, February 20, 1864, w: tamże, s. 460-462; D.T. ConNish, The Sable Arm, s. 267-269; D.J. ColES, "Shooting Niggers Sir", s. 65; W.A. DoBAK, Freedom by the Sword, s. 65-68; H. B. HARGRove, Black Union Soldiers, s. 165-167.

${ }^{15}$ D.J. Coles, "Shooting Niggers Sir", s. 73.

${ }^{16}$ Tamże, s. 74; N.A. TRUdEAU, Like Men of War, s. 151.

${ }^{17}$ Tamże; D. J. Coles, "Shooting Niggers Sir", s. 76.

${ }^{18}$ Tamże, s. 74; N.A. TRUdEAU, Like Men of War, s. 151. 
czyć, że część przypadków była inspirowana gorącymi zachętami ze strony oficerów ${ }^{19}$. Zachowały się również relacje wskazujące na to, że konfederaccy oficerowie osobiście dokonywali egzekucji Murzynów strzałem w głowę ${ }^{20}$.

Niestety na podstawie zachowanego materiału źródłowego niemożliwe jest ustalenie dokładnej liczby zaginionych czarnych, którzy zginęli w czasie bitwy, zostali zamordowani zaraz po niej lub schwytani i odesłani do obozów jenieckich. Rekordy trzech pułków kolorowych podają liczbę 158 zaginionych. Z kolei raport konfederackiego chirurga wspomina o 102 rannych Murzynach w rękach Południowców. Wstępne badania potwierdzają jednak, że około 25-50 żołnierzy zostało zabitych zaraz po bitwie, natomiast kolejnych około 50-60 wysłano do obozów jenieckich (głównie Andersonville). $\mathrm{Z}$ tej liczby około $20-25 \mathrm{w}$ późniejszym czasie wymieniono. Byli to jedyni ocaleni spośród 158 kolorowych żołnierzy, których oficjalnie uznano za zaginionych po bitwie pod Olustee ${ }^{21}$.

\section{PLYMOUTH (KAROLINA PÓŁNOCNA) - 20 KWIETNIA 1864}

Wiosną 1864 r. obszar Karoliny Północnej zdecydowanie leżał poza sferą zainteresowań wojskowych Unii, zwłaszcza wobec przygotowywanej na wielką skalę ofensywy gen. Granta w Wirginii. Co więcej, ich siły na terenie stanu były stopniowo redukowane, co z kolei stwarzało szansę dla konfederatów. Stąd też nie dziwi fakt, że gen. Lee zezwolił w pierwszej połowie roku na oddelegowanie z Armii Północnej Wirginii części oddziałów w celu przeprowadzenia akcji zaczepnych na terenie Karoliny Północnej. Południowcy działali pod presją czasu. Doskonale zdawali sobie bowiem sprawę z faktu, że rozpoczęcie ofensywy przez armię Granta wymusi zaprzestanie operacji w Karolinie Północnej i odesłanie wojsk z powrotem na front do Wirginii. Jedną z takich właśnie akcji było oblężenie Plymouth przez dywizję gen. bryg. Roberta F. Hoke'a ${ }^{22}$.

\footnotetext{
${ }^{19} \mathrm{~W}$ swoich powojennych wspomnieniach Lawrence Jackson z 2. pkaw z Florydy podał np., że dowódca jednostki, płk Abner McCormick, tuż przed rozpoczęciem bitwy takimi oto słowami zachęcał swoich żołnierzy do walki: „Towarzysze i żołnierze 2. pkaw z Florydy idziemy do tej walki po zwycięstwo. Armia generała Seymoura złożona jest w większości z Murzynów z Georgii i Karoliny Południowej, którzy przybyli tu kraść, rabować i najechać nasz stan, mordować, zabijać i gwałcić nasze żony, córki i ukochane. Dajmy im nauczkę. Nie będę brał w tej walce do niewoli żadnego Murzyna". D.J. Coles, "Shooting Niggers Sir”, s. 73.

${ }^{20}$ Tamże, s. 76; N.A. TRUdEAU, Like Men of War, s. 151.

${ }^{21}$ D.J. Coles, "Shooting Niggers Sir", s. 76-80; W.A. DoBAK, Freedom by the Sword, s. 68-70.

${ }^{22}$ W.T. Jordan Jr., G.W. Thomas, Massacre at Plymouth April 20, 1864, w: Black Flag Over Dixie, s. 156.
} 
Garnizon składał się w tym czasie z 3244 ludzi $\left(2844\right.$ z $\operatorname{armii}^{23}$ i 410 z marynarki ${ }^{24}$ ), w tym około 80 czarnoskórych rekrutów oczekujących na przydział do jednostek, 10 czarnych kucharzy z białych regimentów, 111 czarnych marynarzy, 166 białych unionistów z Karoliny Północnej (tzw. Buffaloes), pod dowództwem gen. bryg. Henry'ego W. Wessellsa. W mieście przebywało jeszcze ok. 1000 „kontrabandy” obojga płci oraz około 300 białych cywili, co zwiększało „wojenną” populację Plymouth do około 4500 osób. Przeciwko tym siłom gen. Hoke miał do dyspozycji trzy brygady piechoty, regiment kawalerii i trzy bataliony artylerii (około 35 dział), łącznie około 7000 ludzi ${ }^{25}$. Mimo ponaddwukrotnej przewagi konfederatów garnizon Plymouth był dobrze zaopatrzony i przygotowany do obrony.

Walki rozpoczęły się 17 kwietnia, bez większych jednak sukcesów po stronie nacierających. Następnego dnia Południowcy przeprowadzili nieudany atak na Fort Gray. Udało im się także poważnie uszkodzić wiozącą amunicję do fortu kanonierkę Bombshell. Trafiona poniżej linii wody zawróciła do Plymouth, gdzie ostatecznie zatonęła. Wieczorem konfederaci dokonali pierwszego poważniejszego wyłomu w systemie obrony, zmuszając do kapitulacji Fort Wessells ${ }^{26}$. Rankiem 19 kwietnia siły Hoke'a zostały poważnie wzmocnione. W pobliże Plymouth dotarł pancernik Albemarle, wspomagany przez parowiec Cotton Plant. Jednostka z miejsca przystąpiła do działania, taranując i zatapiając Southfield. Miami po krótkiej walce uciekła w dół rzeki. A wraz z nią pozostałe kanonierki: Whitehead i Ceres. Rzeka

\footnotetext{
${ }^{23}$ Siły federalne składały się z: 16. pp z Connecticut (463 ludzi), 85. pp z Nowego Jorku (544), 101. pp z Pensylwanii (409), 103. pp z Pensylwanii (485), komp. „B” i „E” 2. pp z Karoliny Północnej (166), komp. „A” i „F” 12. pkaw z Nowego Jorku (121), komp. „G” i „H” 2. pac z Massachusetts (269), 24. bat z Nowego Jorku, nieprzydzielonych rekrutów (245) i oficerów sztabowych (10). Tamże, s. 153, 157-158; No. 3. Reports of Brig. Gen. Henry W. Wessells, U. S. Army, commanding Sub-district of the Albemarle, w: OR, seria 1, t. XXXIII, Washington 1891, s. 297, 301.

${ }^{24}$ Były to załogi kanonierek Southfield (139 ludzi), Miami (137), Whitehead (53), Ceres (45), Bombshell (ok. 20) i łodzi parowej Dolly (ok. 16). W.T. JordAn JR., G.W. ThOMAs, Massacre at Plymouth, s. 158.

${ }^{25}$ Konfederackie siły były zorganizowane następująco: piechota - gen. bryg. Matt W. Ransom (8., 24., 25., 35., 56. pp z Karoliny Północnej), płk John T. Mercer (6., 21., 43. pp z Karoliny Północnej, 21. pp z Georgii), płk William R. Terry (1., 3., 7., 11., 24. pp z Wirginii); kawaleria płk James Dearing (8. konfederacki pkaw); artyleria - bataliony ppłk. Henry T. Guiona, mjr. Edgara Fearn Moseley'a i mjr. Johna Postell Williamsona Reada. Tamże, s. 157.

${ }^{26}$ No. 3. Reports of Brig. Gen. Henry W. Wessells, U. S. Army..., w: OR, seria 1, t. XXXIII, s. 296-298; No. 4. Report of Lieut. Lucien A. Butts, Eighty-fifth New York Infantry, w: tamże, s. 301-303; No. 6. Abstract from Record Events on return of the District of North Carolina for April, 1864, w: tamże, s. 305.
} 
Roanoke w pobliżu Plymouth była całkowicie pod kontrolą konfederatów, co nie pozostało bez wpływu na morale obrońców ${ }^{27}$.

O świcie 20 kwietnia brygada Ransoma uderzyła od wschodu, zdobywając Fort Comfort i wdzierając się do miasta, gdzie rozgorzała „najbardziej przerażająca walka uliczna" z oddziałami federalnymi. Nic nie było w stanie zatrzymać nacierających konfederatów. Niedobitki garnizonu schroniły się bądź w Fort Williams, bądź w umocnionym obozie na zachodnich obrzeżach Plymouth. Wobec szybkiej kapitulacji obozu Południowcy skupili całą swoją uwagę na Fort Williams. Generał Hoke wystosował żądanie bezwarunkowej kapitulacji. Wessells początkowo odmówił, wkrótce jednak jednoczesny ostrzal prowadzony od strony rzeki przez Albemarle oraz od strony lądu przez artylerię skłonił generała do zmiany decyzji i wywieszenia białej flagi ${ }^{28}$. Warto tu zaznaczyć, że kapitulacja Fort Williams nie była równoznaczna z natychmiastowym zakończeniem walk. Część oddziałów federalnych kontynuowała jeszcze opór. Na przykład Fort Gray poddał się dopiero po kilku godzinach na wyraźny rozkaz Wessellsa ${ }^{29}$.

Według różnych szacunków w ręce konfederatów dostało się od 2200 do 2600 jeńców, w tym około 400 czarnych (cywili i wojskowych). Automatycznie rodzi się pytanie, co stało się z pozostałymi Afroamerykanami przebywającymi w Plymouth $\mathrm{w}$ chwili rozpoczęcia oblężenia. Około 400 cywili najprawdopodobniej uciekło bądź zostało ewakuowanych w ciągu pierwszych trzech dni walk. Rankiem 20 kwietnia w Plymouth wciąż przebywało jednak 871 czarnoskórych. Jeśli do konfederackiej niewoli trafiło około $400 \mathrm{z}$ nich, to $\mathrm{z}$ prostego rachunku wynika, że wciąż brakuje nam 471 osób $^{30}$.

Niezaprzeczalnym faktem pozostaje, że w którymś momencie rankiem 20 kwietnia znaczna grupa Murzynów i unionistów zdecydowała się na desperacki krok. Jeden cywili przebywających w Plymouth opisał to wydarzenie w liście do „Raleigh Daily Confederate”: „około 6.00 rano duża grupa, licząca może 600 Murzynów i Buffaloes [unionistów], wyszła z [Fort Williams] i ruszyła w kierunku najbliższego punktu bagna Pawia [Peacock swamp]. Trzy kompanie kawalerii i jedna piechoty polowały na nich cały

${ }^{27}$ Tamże; No. 3. Reports of Brig. Gen. Henry W. Wessells, U. S. Army..., w: OR, seria 1, t. XXXIII, s. 298-299.

${ }^{28}$ Tamże, s. 299; No. 6. Abstract from Record Events on return of the District of North Carolina for April, 1864, w: OR, seria 1, t. XXXIII, s. 305; W.T. JORDAN JR., G.W. THOMAS, Massacre at Plymouth, s. 161-162.

${ }^{29}$ Tamże, s. 163.

${ }^{30}$ Tamże, s. 163-164, 168-171. 
dzień i niemal wszyscy zostali zabici. Przypuszczam, że nikogo nie wzięto do niewoli" 31 .

Podobny los najprawdopodobniej spotkał także czarnoskórych złapanych bezpośrednio w Plymouth. Starszy sierżant Oliver W. Gates z 16. pp z Connecticut zapisał w swoim pamiętniku: „[konfederaci] nie okazywali Murzynom litości, [co więcej] zastrzelili kilku z zimną krwią". Inni wspominali, że Afroamerykanie złapani $\mathrm{z}$ jakimkolwiek elementem ekwipunku żołnierskiego (bronią, mundurem, itp.) zostali ustawieni w linii i rozstrzelani przez pluton egzekucyjny ${ }^{32}$. Najlepiej znana, najbardziej szczegółowa i szokująca, a jednocześnie budząca pewne wątpliwości relacja pochodzi jednak od niepiśmiennego czarnego żołnierza Samuela Johnsona, przedstawiającego siebie jako starszego sierżanta z komp. „D” 2. U.S. Colored Cavalry, który rzekomo pomagał por. George'owi W. Frenchowi przy rekrutacji do jednostki. Po kapitulacji Plymouth Johnson dostał się do niewoli, z której zbiegł po około 8 tygodniach. 11 lipca 1864 r. złożył pod przysięgą następujące oświadczenie dotyczące brutalnego traktowania czarnoskórych przez oddziały Hoke'a. „Po zdobyciu Plymouth przez siły rebeliantów wszyscy Murzyni, którzy zostali znalezieni w niebieskich mundurach lub z innymi widocznymi oznakami żołnierza Unii na sobie, zostali zabici. Widziałem, jak niektórzy zostali zaciągnięci do lasu i powieszeni. Innych widziałem rozebranych z ubrań, a następnie ustawionych na brzegu rzeki z twarzami zwróconymi w stronę wody i tam zostali rozstrzelani. Jeszcze inni zostali zabici mocnymi uderzeniami kolb karabinów w rękach rebeliantów. Nie wszyscy zostali zabici w dniu kapitulacji. Tych, którzy [przeżyli] umieszczono w pomieszczeniu z ich [białymi] oficerami, których wcześniej przeciągnięto przez miasto z linami wokół szyi, tam ich trzymano w zamknięciu aż do następnego ranka, kiedy zabito pozostałych czarnych żołnierzy"33. Robert Ould, konfederacki komisarz ds. wymiany jeńców, otrzymawszy kopię oświadczenia Johnsona, kategorycznie zaprzeczył podawanym przez sierżanta informacjom. Powoływał się przy tym na relacje unijnych oficerów przebywających wówczas $\mathrm{w}$ konfederackiej niewoli. W przypadku relacji Johnsona faktycznie wygląda na to, że doszło do jakiejś manipulacji. Wątpli-

\footnotetext{
${ }^{31}$ Wymouth T. Jordan Jr. i Gerald W. Thomas przytaczają w swoim artykule wiele innych relacji (np. por. William L. Cloptona, szer. Franka P. O'Briena, por. Bernarda F. Blackslee'a, adiutanta Jacoba H. Longeneckera, por. Alonzo Coopera, kpt. Johna Donaghy'ego), które generalnie potwierdzają taką właśnie wersję wydarzeń. Zob. tamże, s. 172-173.

32 Tamże, s. 173-174.

${ }^{33}$ Tamże, s. 175-176; B. F. Butler do U. S. Granta (12 lipca 1864), w: OR, seria 2, t. VII, Washington 1899, s. 459-460 [załącznik: oświadczenie Samuela Johnsona (11 lipca 1864)].
} 
wości budzi bowiem nie tylko sama osoba autora (w czasie bitwy o Plymouth starszym sierżantem w 2. USCC był bowiem niejaki Henry Williams, żołnierz zaś imieniem Samuel Johnson nigdy nie służył w tej jednostce), ale i jego relacja (w jaki sposób był on w stanie zobaczyć tak wiele i tak różnych aktów przemocy, podczas gdy wielu innych świadków nie widziało żadnych). Wydaje się, że nie bez znaczenia była tu osoba Benjamina Butlera, który najwyraźniej chciał oskarżyć konfederatów o masakrę ${ }^{34}$.

Mimo wątpliwej wartości niektórych źródeł (zwłaszcza powojennych relacji) nie można zaprzeczyć, że w Plymouth grupa Murzynów (wojskowych i cywili) oraz unionistów została zabita w okolicznościach podchodzących pod pojęcie masakry. Zgodnie z ustaleniami współczesnych autorów w pewnym momencie tuż przed kapitulacją generała Wessellsa grupa około 500 czarnych i 50 unionistów w obawie o swoje życie rzuciła się do ucieczki w kierunku bagien. Konfederacka piechota i kawaleria otworzyły ogień i zaatakowały uciekinierów zabijając tych, którzy odmówili zatrzymania się. Ci, którzy dotarli do bagien, byli ścigani przez co najmniej dwie kompanie piechoty i kawalerię płk. Dearinga. Większość złapanych unionistów i czarnych (głównie cywili) przeżyła, niektórzy jednak z umundurowanych Afroamerykanów zostali rozstrzelani. W tym samym czasie w Plymouth trwało zwyczajowe $\mathrm{w}$ takich sytuacjach plądrowanie miasta przez konfederatów. Jest wielce prawdopodobne, że część Murzynów złapanych w mundurach Unii została zastrzelona na miejscu, część zabito później w dokach (23 lub 24 kwietnia). Zamordowana została także pewna grupa czarnych cywili. Większość tych mordów popełniali pojedynczy żołnierze, nie da się jednak wykluczyć że jeden lub dwa incydenty były udziałem plutonu egzekucyjnego. Brak dowodów na to, aby gen. Hoke w jakikolwiek sposób zachęcał swoich żołnierzy do masakry czarnoskórych ${ }^{35}$.

Liczba zabitych Afroamerykanów w Plymouth 20 kwietnia najprawdopodobniej nie przekroczyła 10 . Kolejnych 15 mogło zostać rozstrzelanych 23 lub 24 kwietnia. 40 zginęło w czasie ucieczki z pola bitwy, 40 zostało zabitych podczas pościgu na bagnach, a 10 poległo w okolicznościach, które moglibyśmy uznać za uczciwą walkę. Około 350 udało się zbiec, a 400 dostało się do niewoli. Czy zatem możemy mówić o masakrze czarnoskórych w Plymouth. Zdecydowanie tak, choć jej rozmiary są trudne do oszacowania. Część z zabitych zginęła podczas ucieczki, kiedy trwała jeszcze bitwa. Ostrzał takich uciekinierów jest dopuszczalny przez prawo wojenne. Warto

\footnotetext{
${ }^{34}$ W.T. Jordan JR., G.W. Thomas, Massacre at Plymouth, s. 177, 186-187.

${ }^{35}$ Tamże, s. 190-191.
} 
jednak zauważyć, że głównym bodźcem, który pchnął tak znaczną grupę Murzynów i unionistów do tego desperackiego kroku nie był strach przed konfederacką niewolą, ale obawa przed mordem $\mathrm{z}$ rąk Południowców. Sytuację dodatkowo komplikowała obecność w tej grupie cywilów, którzy również znaleźli się wśród ofiar rebeliantów. O ile jednak w tym wypadku część zgonów można zrzucić na karb panującego chaosu, o tyle trudno znaleźć jakiekolwiek usprawiedliwienie dla mordów popełnionych po bitwie na tych, którzy zaprzestali walki, rzucili broń i oddali się w ręce wroga. Tak wąska definicja masakry w przypadku Plymouth wciąż obejmuje około 50 osób ${ }^{36}$.

\section{BITWA O KRATER (WIRGINIA) - 30 LIPCA 1864}

Była to jedna $\mathrm{z}$ największych bitew $\mathrm{z}$ udziałem kolorowych oddziałów i jednocześnie jedna $\mathrm{z}$ najbardziej tragicznych kart w historii tych oddziałów w czasie wojny secesyjnej. Głównodowodzący wojskami Unii, gen. Ulysses S. Grant, w swojej korespondencji z szefem sztabu gen. mjr. Henrym W. Halleckiem nazwał ją najsmutniejszym wydarzeniem, którego był świadkiem w czasie wojny ${ }^{37}$. W czerwcu i lipcu 1864 r. na odcinku trzymanym przez IX Korpus gen. mjr. Ambrose'a E. Burnside'a dzięki intensywnie prowadzonym podkopom federalnym udało się umieścić pod konfederackimi liniami obronnymi Petersburga 8 tys. funtów prochu (ok. $3629 \mathrm{~kg}$ ). Cel tych działań był następujący: 1) wysadzenie miny w celu stworzenia wyłomu w konfederackich liniach obronnych; 2) zajęcie dominującego nad okolicą Cemetery Hill, co miało zmusić Południowców do ewakuacji Petersburga i Richmond, a w efekcie doprowadzić do zakończenia wojny ${ }^{38}$.

30 lipca 1864 r. o godz. 4.45 nastąpiła detonacja ładunku. Bezpośrednio w wyniku eksplozji zginęło 278 konfederatów z 18. i 22. pp z Karoliny Południowej należących do obsadzającej ten odcinek brygady gen. bryg. Stephena Elliotta Jr. Wybuch stworzył wielką dziurę w ziemi, mierzącą około 45-60 m długości, $18 \mathrm{~m}$ szerokości i $9 \mathrm{~m}$ głębokości ${ }^{39}$. Wkrótce po

\footnotetext{
${ }^{36}$ Tamże.

${ }^{37}$ U.S. Grant do H. W. Hallecka (1 sierpnia 1864), w: OR, seria 1, t. XL, cz. 1, Washington 1892, s. 17.

${ }^{38}$ W.A. DobaK, Freedom by the Sword, s. 355-357; H.B. Hargrove, Black Union Soldiers, s. 183-184; B.A. Suderow, The Battle of the Crater. The Civil War's Worst Massacre, w: The Black Flag Over Dixie, s. 203; N.A. TRUdEAU, Like Men of War, s. 230-236.

${ }^{39}$ Tamże, s. 236-238; No. 175. Reports of Maj. Gen. Ambrose E. Burnside, U. S. Army, commanding Ninth Army Corps, of operations June 12-July 30, w: OR, seria 1, t. XL, cz. 1, s. 527; W.A. DoBAK, Freedom by the Sword, s. 359.
} 
detonacji do ataku ruszyły trzy białe dywizje IX Korpusu ${ }^{40}$, które podjęły próbę rozszerzenia wyłomu. Niestety wskutek fatalnego dowodzenia natarcie szybko zostało powstrzymane, a oddziały zepchnięte z powrotem do „krateru", jak zaczęto nazywać miejsce eksplozji ${ }^{41}$. Tymczasem Burnside zamiast wycofać swoje wojska, pchnął do walki 4. Dywizję gen. bryg. Edwarda Ferrero, którą tworzyły dwie brygady pod dowództwem płk. Joshui K. Sigfrieda (27., 30., 39., 43. USCT) i płk. Henry'ego Goddarda Thomasa (19., 23., 28., 29., 31. USCT) ${ }^{42}$.

Mimo silnego oporu konfederatów brygada Sigfrieda zdołała opanować konfederackie umocnienia, biorąc do niewoli ok. 200 jeńców, zdobywając sztandar i odbijając jeden federalny. Tymczasem atakująca na lewo brygada płk. Thomasa została odparta $\mathrm{z}$ dużymi stratami w prowadzącym uderzenie 31. USCT. Wkrótce nadszedł rozkaz od gen. Ferrero, który nie towarzyszył swoim oddziałom, by kontynuować natarcie w kierunku Cemetery Hill ${ }^{43}$. Obaj pułkownicy jeszcze raz poderwali żołnierzy do uderzenia. Prawie natychmiast federalni natknęli się na wściekły kontratak brygad z Wirginii (płk David A. Weisiger) i Georgii (ppłk Matthew R. Hall) należących do

\footnotetext{
${ }^{40}$ Były to 1. Dywizja gen. bryg. Jamesa H. Lidlie’a, 2. Dywizja gen. bryg. Roberta B. Pottera i 3. Dywizja gen. bryg. Orlando B. Willcoxa. Według pierwotnego planu uderzenie miała poprowadzić 4. Dywizja gen. bryg. Edwarda Ferrero, wobec jednak sprzeciwu dowódcy Armii Potomaku, gen, mjr. George'a Meade'a, zadanie to powierzono trzem białym dywizjom IX Korpusu. Tamże, s. 357; H.B. HARgrove, Black Union Soldiers, s. 184; N.A. TrudEAU, Like Men of War, s. 234-235.

${ }^{41}$ Tamże, s. 238; No. 175. Reports of Maj. Gen. Ambrose E. Burnside, U. S. Army..., w: OR, seria 1, t. XL, cz. 1, s. 527-528; No. 176. Reports of Brig Gen. James H. Ledlie, U.S. Army, commanding First Division, of operations June 17 and July 30, w: tamże, s. 535-536; No. 183. Reports of Brig. Gen. Robert B. Potter, U.S. Army, commanding Second Division, w: tamże, s. 547549; No. 195. Reports of Brig. Gen. Orlando B. Willcox, U. S. Army, commanding Third Division, w: tamże, s. 574-575; D.T. CoRnish, The Sable Arm, s. 275; W.A. DoBAK, Freedom by the Sword, s. 359-362.

${ }^{42}$ Burnside tłumaczył się później, że działał w myśl rozkazów dowódcy Armii Potomaku, gen. mjr George'a G. Meade'a. Tamże, s. 362; No. 4. Record of the Court of Inquiry on the Mine Explosion, w: OR, seria 1, t. XL, cz. 1, s. 140-141 [załączniki: W) A.A. Humphreys do A.E. Burnside'a (30 lipca 1864, godz. 5.40); Y) G.G. Meade do A. E. Burnside'a (30 lipca 1864, godz. 6.00)]; No. 7. Return of Casualties in the Union Forces, w: tamże, s. 248; No. 175. Reports of Maj. Gen. Ambrose E. Burnside, U. S. Army..., w: tamże, s. 528; D.T. Cornish, The Sable Arm, s. 275.

${ }^{43}$ No. 4. Record of the Court of Inquiry on the Mine Explosion, w: OR, seria 1, t. XL, cz. 1, s. 93, 128 [zeznania gen. bryg. Edwarda Ferrero; opinia sądu dotycząca działań generałów Ledlie'a i Ferrero]; No. 212. Report of Col. Joshua K. Sigfried, Forty-eight Pennsylvania Infantry, commanding First Brigade, of operations July 30, w: tamże, s. 596; No. 213. Report of Col. Henry G. Thomas, Nineteenth U. S. Colored Troops, commanding Second Brigade, of operations July 30, w: tamże, s. 598; W.A. DoBAK, Freedom by the Sword, s. 362-363; N.A. TRUDEAU, Like Men of War, s. 239-242.
} 
dywizji gen. bryg. Williama Mahone'a. Po zaciekłej walce obie kolorowe brygady zostały wyrzucone $\mathrm{z}$ konfederackich umocnień i zepchnięte do krateru, gdzie dołączyły do tłoczących się tam już białych oddziałów, potęgując jedynie zamieszanie. Między 9.30 a 13.00 Południowcy przeprowadzili co najmniej cztery uderzenia na krater, które ostatecznie zakończyły się jego zdobyciem ${ }^{44}$.

Na podstawie zachowanych źródeł można stwierdzić, że 30 lipca doszło do przynajmniej kilku masakr tak w czasie, jak i już po bitwie o krater. Pierwsza $\mathrm{z}$ nich miała miejsce $\mathrm{w}$ czasie konfederackiego kontrataku na okopy zajęte przez brygadę Sigfrieda. Żołnierze Weisigera i Wrighta zabijali zarówno rannych, jak i chcących oddać się do niewoli. Nie oszczędzono także żołnierzy USCT, którzy zostali odesłani na tyły jako jeńcy. George Bernard z 12. pp z Wirginii należącego do brygady Weisigera wspominał później, że „w ciągu tych 10 minut całe dno okopu zostało usłane martwymi ciałami Murzynów, w niektórych miejscach tak licznie, że przechodząc wzdłuż okopu trudno było na któreś nie nadepnąć" ${ }^{45}$. Inny z żołnierzy tej samej jednostki, szeregowy Henry Van Lewvenigh Bird, tak opisał to starcie w liście do ukochanej: „Nie zadawano tam ran urlopowych ${ }^{46}$ ani nie okazywano litości. Błagania o łaskę i jęki rannych były jednako uciszane przez śmierć. [...] Okrzyk bojowy atakujących Murzynów «Zero litości» spotkał się z nieugiętą odpowiedzią «Amen» i bez oddania pojedynczego strzału zbliżyliśmy się do nich. Walczyli jak buldogi i umierali jak żołnierze. Południowe bagnety ociekały krwią i po krótkiej, ale zaciekłej walce umocnienia były nasze. Jedyne dźwięki, które wówczas zakłócały ciszę, wydawał jakiś ranny nieszczęśnik błagający o wodę i uciszony wrażonym w niego bagnetem, który niezawodnie zdawał się mówić «Pij swoją krew. Nie zaznasz już pragnienia»" $" 47$.

Po odparciu dywizji Ferrero do krateru ludzie Mahone'a między 10.00 a 12.00 przeczesywali okoliczne schrony, poszukując i mordując ukrywających się w nich Murzynów. Tych, których oszczędzono, odesłano na tyły. Wielu jeńców zostało jednak zabitych w kolejnej masakrze. Zdarzenia te

${ }^{44}$ Tamże, s. 242-247; No. 211. Report of Brig. Gen. Edwar Ferrero, U. S. Army, commanding Fourth Division, w: OR, seria 1, t. XL, cz. 1, s. 595-596; No. 212. Report of Col. Joshua K. Sigfried, Forty-eight Pennsylvania Infantry..., w: tamże, s. 597; No. 213. Report of Col. Henry G. Thomas, Nineteenth U. S. Colored Troops..., w: tamże, s. 598-599; W.A. DoBAK, Freedom by the Sword, s. 363-365.

${ }^{45}$ G.S. BernARD, War Talks of Confederate Veterans, Petersburg 1892, s. 160.

${ }^{46} \mathrm{~W}$ oryginale „furlough wounds” - chodzi tu o ranę, która była na tyle poważna, by dostać urlop/przepustkę, ale nie na tyle zła, by trwale okaleczyć lub zabić żołnierza.

${ }^{47}$ Cyt. za: B.A. Suderow, The Battle of the Crater, s. 205. 
opisał w liście płk William Pegram: „Sądzę, że ponad dwustu Murzynów znalazło się za naszymi liniami [...]. Nie wierzę, by wielu ponad połowa z nich kiedykolwiek dotarła na tyły. Można było zobaczyć ich leżących martwych wzdłuż całej trasy na tyły. Było tam niespełna 600 zabitych w tym 400 Murzynów. Jak tylko się do nich zbliżyliśmy rzucali swoją broń w geście poddania, ale nie pozwolono im na to. W każdym schronie, który widziałem był jeden lub dwóch martwych Murzynów, którzy uchylili się od walki ale zostali znalezieni i zabici przez naszych ludzi" ${ }^{48}$.

Do czwartej masakry doszło już po kapitulacji federalnych w kraterze. William A. Day z 49. pp z Karoliny Północnej relacjonował po wojnie, że konfederaci zatrzymali się na krawędzi krateru i oddali salwę do tłoczących się w dole federalnych, a nastepnie skoczyli w dół, rażąc kolbami przerażonego wroga. „Jak te czaszki Murzynów pękały pod uderzeniami. [...] Kiedy dotarłem na miejsce pokryli już cały teren Murzynami z porozbijanymi głowami i szukali w schronach dalszych, oficerowie próbowali ich

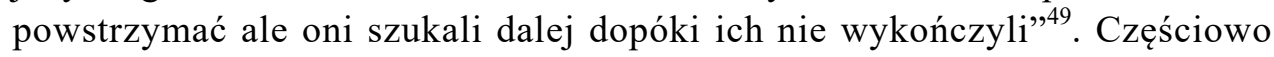
winę za tę masakrę ponosi gen. Mahone, który przed walką miał zachęcać swoich podkomendnych, by nie okazywali litości czarnym żołnierzom Unii. Miała być to zemsta za okrzyki bojowe wznoszone przez oddziały USCT („Pamiętajcie Fort Pillow! Zero litości”) i niedawanie pardonu konfederatom. Dopiero pod koniec bitwy Mahone miał wydać rozkaz, by „nie zabijać całkiem wszystkich"

To, że doszło do masakry, nie ulega wątpliwości. Jakie jednak były jej rzeczywiste rozmiary? Oficjalny raport strat poniesionych przez 4. Dywizję podaje, że z jej szeregów ubyło 209 zabitych, 697 rannych i 421 zaginionych. Łącznie 1327 ludzi ${ }^{51}$. Sugerowana liczba zabitych wydaje się nieprawdopodobnie niska przynajmniej $\mathrm{z}$ dwóch powodów. Po pierwsze, konfederaci twierdzili, że pochowali 750 federalnych po bitwie. Tymczasem unijny raport dotyczący strat poniesionych w walkach o krater podaje, że po stronie Unii zostało zabitych tylko 504 (w tym 209 czarnych) ${ }^{52}$. Innymi

\footnotetext{
${ }^{48}$ Cyt. za: tamże, s. 205-206.

${ }^{49}$ Tamże, s. 206; W.A. DAY, A True History of Company I, 49th Regiment, North Carolina Troops in the Great Civil War between the North and South, Newton 1893, s. 84.

${ }^{50}$ D.T. Cornish, The Sable Arm, s. 275-276; B.A. SudERow, The Battle of the Crater, s. 206; B.F. PHILlips, Wilcox's Alabamians in Virginia, „Confederate Veteran” 1907, t. XV, nr 11, s. 490.

${ }^{51} \mathrm{Na}$ podstawie danych archiwalnych B. Suderow podaje nieco inne dane: 219 zabitych, 681 rannych i 410 zaginionych. Łącznie 1310 ludzi. No. 7. Return of Casualties in the Union Forces, w: $O R$, seria 1, t. XL, cz. 1, s. 248; H.B. HARgrove, Black Union Soldiers, s. 186; B.A. SudERow, The Battle of the Crater, s. 207; N. A. TRudeau, Like Men of War, s. 247.

${ }^{52}$ No. 7. Return of Casualties in the Union Forces, w: OR, seria 1, t. XL, cz. 1, s. 249.
} 
słowy, konfederaci twierdzili, że pochowali 246 ciał więcej, niż wykazuje federalny raport strat. Poza tym, chociaż ten sam dokument wskazuje, że ponad 400 żołnierzy 4. Dywizji zostało uznanych za zaginionych, Południowcy twierdzili, że wzięli do niewoli jedynie około 200 Murzynów. Bryce Suderow, analizując listę zaginionych, ustalił, że aż 205 z nich zostało zabitych, 13 śmiertelnie rannych, 62 odniosło rany $w$ walce, 3 śmiertelnie rannych trafiło do niewoli, 13 rannych $\mathrm{w}$ walce także podzieliło ten los, podobnie jak 72 ,zdrowych” żołnierzy. Pozostali nie stanowili strat bojowych poniesionych przez kolorowe regimenty. Po naniesieniu tych danych na pierwotną listę strat okazuje się, że ubytek ludzi w 4. Dywizji wyniósł 423 zabitych, 757 rannych, 89 w niewoli. Łącznie 1269 żołnierzy. Stosunek zabitych do rannych w regimentach USCT wyniósł zatem 1 do 1.8 (przy średniej dla całej wojny 1 do 4.8). Tylko dwa inne starcia mogą się pod tym względem równać z bitwą o krater - Fort Pillow i Poison Spring ${ }^{53}$.

\section{OKRUCIEŃSTWA WOJNY CZY PRZEJAW RASIZMU? ŹRÓDŁA ZACHOWAŃ ŻOŁNIERZY KONFEDERACJI WOBEC ŻOŁNIERZY USCT}

Relacje dotyczące masakr żołnierzy kolorowych są niezwykle szokujące i psują tworzony przez lata niemal romantyczny wizerunek wojny secesyjnej jako starcia zwaśnionych braci. Ze względu na politykę pojednania zarówno na Południu, jak i na Północy duży nacisk kładziono na „bezrasowy” opis konfliktu. Nie dziwi zatem fakt, że tak długo starano się przemilczeć wydarzenia, do których doszło pod Olustee, w Plymouth czy w bitwie o krater. O ile bowiem „biała Ameryka” w końcu dostrzegła wkład 180 tys. Afroamerykanów w wojnę, o tyle wciąż opiera się przed właściwą oceną zjawiska rasizmu, który był obecny tak przed, w czasie, jak i po wojnie, i to zarówno na Południu, jak i na Północy. Zapewne wynika to także z faktu, że zjawisko to wciąż jest obecne w USA ${ }^{54}$.

Jak więc ocenić postępowanie żołnierzy konfederackich wobec ich czarnoskórych przeciwników? Z moralnego punktu widzenia trudno bowiem znaleźć jakiekolwiek usprawiedliwienie dla okrucieństw popełnionych przez

\footnotetext{
${ }^{53}$ B.A. Suderow, The Battle of the Crater, s. 207-209; N. A. TrudeAu, Like Men of War, s. 247.

${ }^{54}$ E. Foner, Give me Liberty! An American History, t. II, From 1865, New York-London 2012, s. 649; M. GRIMSLEY, “A Very Long Shadow”. Race, Atrocity, and the American Civil War, w: Black Flag Over Dixie, s. 232; G.J.W. URwIN, Introduction. Warfare, Race, and the Civil War in American Memory, w: Black Flag Over Dixie, s. 2-3.
} 
rebeliantów. Na pytania o motywy kierujące Południowcami niezwykle trudno udzielić jednoznacznej odpowiedzi. Czy należy w tym wypadku winą obarczyć jedynie rasizm? Z jednej strony taka właśnie odpowiedź, choć najprostsza, wydaje się niepełna. Z drugiej jednak strony polityka rządu Skonfederowanych Stanów Ameryki oraz postępowanie żołnierzy konfederackich wobec Afroamerykanów były tak rażąco rasistowskie, że razem oferują nam najlepsze studium powiązań między rasizmem a okrucieństwami popełnionymi w okresie wojny secesyjnej. W związku z tym, aby właściwie zrozumieć funkcjonujący w połowie XIX wieku biały rasizm, należy sięgnąć nieco głębiej do historii USA, dopiero wówczas możliwe będzie właściwe zrozumienie społeczeństwa, które ta historia stworzyła ${ }^{55}$.

Zasadniczo możemy wyróżnić trzy oblicza białego rasizmu. Po pierwsze, jako konstrukcję ideologiczno-kulturową; po drugie, jako system ekonomicznego wykorzystania; po trzcie, jako pewien fenomen psychologiczny. Według Stownika wyrazów obcych W. Kopalińskiego rasizm to „zespół poglądów o rzekomo nierównej wartości biologicznej, a zatem intelektualnej i społecznej, ras ludzkich (poglądów połączonych zazwyczaj z wiarą we wrodzoną wyższość jakiejś określonej rasy i w jej prawo do panowania nad innymi)" "56. Antropolog Audrey Smedley, idąc dalej, udowadnia, że rasa jest wynalazkiem socjokulturowym i nie stanowi naukowej rzeczywistości. Jest ona, jak twierdzi A. Smedley, „zbiorem przekonań i poglądów dotyczących różnic między ludźmi, a nie samych różnic". Co istotne, te przekonania i poglądy nie są odwieczne, a co jeszcze ważniejsze - nie są „naturalnym” sposobem postrzegania ludzi. Wyznacznikiem siły rasizmu była zdolność do utrzymania iluzji, że rasa stanowi naturalną kategorię podziału ludzkości, jak również stopień akceptacji tych poglądów przez większość białych, a nie tylko elity ${ }^{57}$. Ze względu na swój napastliwy charakter rasizm dla wielu jest równoznaczny $\mathrm{z}$ rasową nienawiścią. Tymczasem kwintesencją białego rasizmu jest $\mathrm{w}$ istocie zachowanie przywilejów białych. Co ciekawe, jeśli prześledzimy historię, zobaczymy, że biali mieszkańcy Ameryki nie zawsze cieszyli się uprzywilejowanym statusem, a przynajmniej nie wszyscy.

We wczesnym okresie kolonialnym (XVII wiek) duże znaczenie miały rodzina, religia oraz majątek, spychając kwestię koloru skóry na dalszy plan. Stąd też status pracowników kontraktowych i niewolników wykazywał

\footnotetext{
${ }^{55}$ M. GRIMSLEY, “A Very Long Shadow”, s. 232

${ }^{56}$ W. KopALIŃSKI, Stownik wyrazów obcych i zwrotów obcojęzycznych z almanachem, Warszawa 2000, s. 423.

${ }^{57}$ M. GRIMSLey, “A Very Long Shadow”, s. 233.
} 
w tym czasie wiele podobieństw, praktycznie niwelując wszelkie różnice społeczne między tymi grupami i sprawiając, że biała biedota miała więcej wspólnego z Afroamerykanami niż z bogatą gentry ${ }^{58}$. Dopiero na przełomie XVII i XVIII wieku podjęto pierwsze kroki w kierunku uczynienia niewolnictwa normatywnym statusem ludności czarnej. Wolna ludność kolorowa zaczęła być postrzegana jako pewnego rodzaju anomalia. By to podkreślić, zaczęto poważnie ograniczać jej prawa ${ }^{59}$. Taki stan rzeczy utrzymał się praktycznie przez cały wiek XVIII. Pamiętać jednak należy, że przez całe stulecie rasizm wciąż był raczej zjawiskiem dominującym w środowisku elit. Natomiast biedni biali nadal socjalizowali się z czarnymi. Nie oznacza to oczywiście, że między tymi grupami nie występowały żadne antagonizmy. Były one jednak spowodowane bardziej różnicami kulturowymi niż rasową wrogością ${ }^{60}$.

Pewnego rodzaju nobilitacją było dopuszczenie Murzynów do służby wojskowej w okresie wojny o niepodległość. Washington przez długi czas zwlekał z podjęciem decyzji, ostatecznie jednak nieustanny brak ludzi oraz konieczność przeciwdziałania zaciągowi niewolników do armii przez Wielką Brytanię przekonały go do zmiany zdania. Warto podkreślić, że głównym argumentem przeciwników była możliwość destabilizacji instytucji niewolnictwa. Natomiast zupełnie nieobecne były obawy, które pojawiły się w czasie wojny secesyjnej, tj. że czarni będą miernymi żołnierzami oraz że biali poczują się poniżeni, służąc u ich boku. Z tego też względu Armia Kontynentalna nie doświadczyła rasowej segregacji ${ }^{61}$.

Poważniejsze zmiany przyniósł dopiero wiek XIX. Do 1830 r. zwykłe poczucie wyższości zaczęło ustępować miejsca rasowej nienawiści, której przejawy można zaobserwować w czasie wojny secesyjnej. Trzy główne czynniki były katalizatorem wspomnianych zmian.

Pierwszym było bardzo mocne zaakcentowanie wolności w okresie wojny o niepodległość. Wymagało to bowiem albo zniesienia niewolnictwa, albo znalezienia jakiegoś logicznego usprawiedliwienia, które nie byłoby sprzeczne

\footnotetext{
${ }^{58}$ Główną różnicą między pracownikiem kontraktowym a niewolnikiem była taka, że ten pierwszy miał realne szanse otrzymać wolność, oczywiście pod warunkiem, że dożył do końca kontraktu trwającego najczęściej od 5 do 7 lat. E. FonER, Give Me Liberty!, t. I, To 1877, New York-London 2012, s. 54.

${ }^{59}$ Zakazano służby w milicji, piastowania urzędów, zeznawania w sądzie, głosowania itd. M. GRIMSLey, “A Very Long Shadow”, s. 235.

${ }^{60}$ Tamże, s. 235-236.

${ }^{61}$ Po zakończeniu wojny o niepodległość taka sytuacja powtórzy się w armii amerykańskiej dopiero podczas wojny w Korei (1950-1953). Tamże, s. 236; E. Foner, Give Me Liberty!, t. I, s. 202.
} 
z twierdzeniem: all men are created equal. Północ opowiedziała się za abolicją, stopniowo uwalniając swoich niewolników. Pod koniec XVIII wieku nawet na Południu dominował pogląd, że niewolnictwo jest w istocie „złem koniecznym" ${ }^{\prime 2}$. Z czasem stanowisko to uległo zdecydowanej zmianie. Już w latach trzydziestych XIX wieku uznawano, że stanowi ono podstawę dla instytucji wolnego świata i de facto jest czymś dobrym (ang. positive good). Co więcej, na Południu odrzucano w tym czasie także ideę powszechnego prawa do wolności i równości propagowanej w Deklaracji Niepodległości, uważając, że przyjęcie tej zasady stanowiło jeden $\mathrm{z}$ największych politycznych błędów popełnionych w Ameryce ${ }^{63}$.

Drugim czynnikiem było założenie o rzekomej niższości Afroamerykanów. Był to sposób na łagodzenie napięć społecznych wśród białych. W myśl bowiem tej koncepcji nawet najniżej stojący w hierarchii członkowie wciąż należeli do jednej i tej samej grupy, wyróżniającej się białym

\footnotetext{
${ }^{62}$ Wynikało to z przeświadczenia, że Afroamerykanie byli rasą słabszą, stojącą niżej pod względem tak inteligencji, jak i moralności, a przez to niezdolną do ekonomicznej rywalizacji z białymi. Stąd też należało wziąć ich „pod opiekę”, gdyż ewentualna emancypacja byłaby dla Murzynów katastrofą. W podobnym tonie na temat przeszkód stojących na przeszkodzie zniesieniu niewolnictwa w Stanach Zjednoczonych wypowiadał się Adam Słoński, który przebywał w USA w latach pięćdziesiątych XIX wieku: „Główną jeszcze przeszkodą stojącą na zawadzie rychłego zniesienia niewolnictwa na Południu jest przyszły los Murzyna. Nie dosyć bowiem jest obdarować go wolnością osobistą: trzeba jeszcze oprócz tego nadać mu pewne prawa jako obywatelowi ziemi, na któréj się zrodził, to jest prawo nabywania ziemi, współubiegania się we wszelkich zawodach, wolnego kształcenia się, a w końcu prawo wybierania i bycia wybieranym na urząd publiczny. I pytam się, czy Murzyn raptownie obdarowany wolnością będzie w stanie korzystać z praw mu nadanych? Śmiało mogę powiedzieć że nie, i niezawodnie każdy bezstronny badacz natury zgodzi się ze mną na to. Wprawdzie Murzyn z czasem, w miarę oświecenia go, będzie się w stanie wykształcić i zająć stosowne miejsce w społeczeństwie, stać mu się użytecznym i korzystać z praw obywatelstwa. Lecz zapytuję się: czyż będzie kiedykolwiek w stanie pozbyć się tego, co go czyni, dla ludzi białych nieznośnym i co go oddzielać zawsze będzie od ich towarzystwa? to jest: niekształtności fizycznej tak ciała, jak i twarzy oraz nieprzyjemnego odoru przypominającego kozła”. M. GRIMSLEY, “A Very Long Shadow”, s. 237; A. SŁońSKI, Poglad na Stany Zjednoczone Pótnocnej Ameryki, oraz na wojnę toczaca się obecnie w tym kraju, i przyczyny, które sa głównym jej powodem, Warszawa 1864, s. 22-23; G.J.W. URwIN, "We Cannot Treat Negroes ... as Prisoners of War". Racial Atrocities and Reprisals in Civil War Arkansas, w: Black Flag Over Dixie, s. 140.

${ }^{63}$ Odzwierciedlenie poglądów na temat niewolnictwa można odnaleźć m.in. w przemówieniach Johna C. Calhouna, jednego z najwybitniejszych mówców Południa pierwszej połowy XIX wieku - zob. On the reception of Abolition Petitions, delivered in the Senate, February 6th, 1837, w: The Works of John C. Calhoun, t. II, New York 1854, s. 631; Remarks Made during the Debate on his Resolutions, in respect to the Rights of the States and the Abolition of Slavery, December 27th, 1837, et seq., w: tamże, t. III, New York 1854, s. 180; Speech On the Oregon Bill, delivered in the Senate, June, 27th, 1848, w: tamże, t. IV, New York 1854, s. 507; George Fitzhugh and the Proslavery Argument (1854), w: Voices of Freedom. A Documentary History, red. E. Foner, t. I, New York-London 2011, s. 207-208; M. Grimsley, “A Very Long Shadow”, s. 236-237.
} 
kolorem skóry. Według Vernona Parringtona „tendencja ta wynikła z logicznego wyjaśnienia sytuacji zharmonizowania dwóch pozornie niedających się pogodzić faktów: systemu niewolnictwa Murzynów i umacniania się demokracji białych”64. „Białość” (ang. whiteness) dawała poza tym wiele wymiernych korzyści, gwarantowała dostęp do ochrony prawnej, udział w życiu politycznym oraz możliwości ekonomiczne. Natomiast darmowa praca niewolników miała stanowić podstawę funkcjonowania gospodarki Południa. Był to jeden z największych ówczesnych paradoksów. Niewolnictwo stanowiło fundament wolności i równości białych. W historiografii fenomen ten określany jest także mianem tzw. demokracji panów (Herrenvolk democracy). Stanowił on wypaczenie założeń XIX-wiecznego liberalizmu, sławiącego własność jako podstawę wolności. Problem polegał bowiem na tym, że na Południu własnością, która wspierała wolność białych, byli niewolnicy ${ }^{65}$.

Trzecim czynnikiem była narastająca obawa przed zmieszaniem ras, które doprowadzi do zatracenia barier i różnic społecznych ${ }^{66}$. Ta niechęć wobec Afroamerykanów jest charakterystyczna dla białych mieszkańców całych Stanów Zjednoczonych. Główna różnica polega jednak na tym, że na Północy przybrała ona formę „rasizmu awersyjnego” (ang. aversive racism), czyli życia z dala od czarnych. Ideałem byłaby sytuacja, w której Murzyni całkowicie zniknęliby z amerykańskiego życia. Takie podejście widoczne jest chociażby $\mathrm{w}$ postulatach ruchu abolicyjnego w pierwszych dekadach XIX wieku, kiedy zakładano, że niewolnicy po otrzymaniu wolności „powrócą" do Afryki ${ }^{67}$. Kiedy zaś okazało się to niemożliwe, na Północy za-

${ }^{64}$ Cyt. za: K. MichaŁeK, Dyplomaci i okręty. Z dziejów polityki zagranicznej Skonfederowanych Stanów Ameryki, Warszawa 1987, s. 49-50.

${ }^{65}$ George Fitzhugh and the Proslavery Argument (1854), w: Voices of Freedom, t. I, s. 208210; P. Derengowski, Polacy $w$ wojnie secesyjnej 1861-1865, Oświęcim 2015, s. 25; M. GrimsLEY, “A Very Long Shadow”, s. 237.

${ }^{66} \mathrm{Na}$ ten temat wypowiadał się także Kacper Tochman, jeden z najwybitniejszych przedstawicieli polskiej emigracji politycznej w USA przed wybuchem wojny secesyjnej, który twierdził, że już twórcy Konstytucji Stanów Zjednoczonych, tworząc podwaliny amerykańskiego społeczeństwa, przyjęli takie zasady, „aby zachować naszą rasę od połączenia się z drugą, bo prawo natury karze upadkiem i wyrodzeniem się wyższej rasy w stopniowo coraz to bardziej zdegenerowane pokolenie mulatów. Że pozbycie się z żył czarnej krwi jest niemożliwe i że krew ta prowadzi do upadku i zaniku rasy wyższej, zostało to już naukowo stwierdzone [...]”. Zob. G. TocHMAN, Dr. Tochman's Letter to the Polish Democratic Societies, „Southern Literary Messenger. A magazine devoted to literature, science and art" 34 (1862), nr 5, s. 322-323. Szerzej o opnii Polaków na temat niewolników i niewolnictwa zob. P. DeRENGOwski, The Polish Voice on Slaves and Slavery in the United States in Mid-Nineteenth Century, w: East Central Europe in Exile, t. II, red. A. Mazurkiewicz, Newcastle upon Tyne 2013, s. 117-132.

${ }^{67}$ Staraniem działającego od 1816 r. Amerykańskiego Towarzystwa Kolonizacyjnego w Zachodniej Afryce założono Liberię. E. FonER, Give me Liberty!, t. I, s. 439-440. 
częto podsycać strach białych mieszkańców przed masowym napływem czarnych. Nawet Abraham Lincoln, w czasie słynnych debat o miejsce w senacie, broniąc się przed oskarżeniami Stephena Douglasa o sprzyjanie ludności murzyńskiej, oświadczył publicznie: „Nie popieram - i nigdy nie popierałem - koncepcji doprowadzenia jakimikolwiek środkami do równości społecznej i politycznej ras białej i czarnej [...] Nie jestem - i nigdy nie byłem - zwolennikiem przyznania Murzynom praw wyborczych, prawa do zasiadania $\mathrm{w}$ ławie przysięgłych czy stworzenia im możliwości zdobycia kwalifikacji do obejmowania urzędów. Nigdy też nie opowiadałem się za tym, aby czarni zawierali małżeństwa z białymi. Dodam jeszcze, że istnieje między rasą białą i czarną naturalna różnica, która, jak sądzę, nigdy nie pozwoli na to, aby żyły one w warunkach społecznej i politycznej równości” ${ }^{68}$. Z kolei na Południu funkcjonował „rasizm władczy” (ang. dominative racism), który zakładał, że Afroamerykanie stanowią konieczny komponent społeczeństwa, ale jedynie pod warunkiem, że pozostają pod pełną kontrolą białych. Do konfrontacji między tymi dwoma wizjami doszło w latach pięćdziesiątych XIX wieku w czasie sporów o status nowo przyłączanych terytoriów ${ }^{69}$.

Wybór Abrahama Lincolna na prezydenta w 1860 r. doprowadził do eskalacji tego konfliktu. Południe, obawiając się, że nowa administracja rozpocznie krucjatę przeciwko niewolnictwu, postanowiło nie czekać i opuścić Unię jeszcze przed końcem kadencji obecnego prezydenta ${ }^{70}$. Wkrótce stany, które dokonały secesji, utworzyły własne państwo - Skonfederowane Stany Ameryki. Jego konstytucja, choć w znacznej mierze będąca kopią tej uchwalonej w 1787 r., została uzupełniona o zapisy dotyczące niewolnictwa. Jednym $\mathrm{z}$ fundamentów, na których opierało się nowe państwo, była - jak twierdził wiceprezydent Alexander H. Stephens - „wielka prawda, że Murzyn nie jest równy białemu człowiekowi; że niewolnictwo, podległość rasie wyższej jest jego naturalnym i moralnym stanem"71. Tymczasem administracja Lincolna początkowo wcale nie zamierzała „mieszać” się w sprawy niewolnictwa, czemu prezydent dał wyraz nie tylko w swoim przemówieniu

${ }^{68}$ P. Derengowski, Polacy $w$ wojnie secesyjnej 1861-1865, s. 184; E. Foner, The Fiery Trial. Abraham Lincoln and American Slavery, New York-London 2010, s. 107-108; The LincolnDouglas Debates (1858), w: Voices of Freedom, t. I, s. 261-265.

${ }^{69}$ M. GRIMSLEY, “A Very Long Shadow”, s. 238.

${ }^{70}$ South Carolina Ordinance of Secession, w: Voices of Freedom, t. I, s. 265-268.

${ }^{71}$ Alexander H. Stephens, The Cornerstone of the Confederacy (1861), w: tamże, s. 269-273; The Constitution of the Confederate States of America, w: Journal of the Congress of the Confederate States of America, 1861-1865, t. I, Washington 1904, s. 851-860. 
inauguracyjnym, ale i w pierwszej fazie wojny ${ }^{72}$. Zresztą nawet już po ogłoszeniu emancypacji w polityce rządu federalnego można zauważyć elementy o wyraźnie rasistowskim podłożu, m.in. niższy żołd dla żołnierzy kolorowych, fatalne warunki dla uciekinierów z Południa w tzw. obozach kontrabandy, zmuszanie do prac fizyczny czy wcielanie wyzwalanych siłą do armii Unii. Oczywiście z perspektywy konfederatów takie „niegodne” postępowanie rządu USA nie wpłynęło na jego ogólną ocenę. Dla nich wszelkie działania wymierzone w niewolnictwo (wykazujące elementy rasistowskie czy też nie) postrzegane były jako zagrażające żywotnym interesom Południa, uzbrajanie zaś Murzynów prowadziło do eskalacji i barbaryzacji konfliktu i powinno być traktowane jako zbrodnia wojenna, za którą winowajcy powinni odpowiedzieć śmiercią ${ }^{73}$.

Warto jednak pamiętać, ze rasizm nigdy nie funkcjonował jako niezależny fenomen. Podobnie jak w okresie porewolucyjnym stanowił jedynie element służący celom politycznym i społeczno-kulturowym białych, tak i w czasie wojny secesyjnej był tylko jednym z czynników wpływających na zachowanie konfederackich żołnierzy. Niepoślednią rolę odgrywała tu także chęć wzięcia odwetu na najeźdźcach, pomszczenia poległych bliskich i towarzyszy broni. Nie można jednak wykluczyć, że uczucie pogardy czy wręcz nienawiści rasowej, przynajmniej do pewnego stopnia, potęgowało emocje na polu walki.

\section{BIBLIOGRAFIA}

ŹRÓDŁA

Alexander H. Stephens, The Cornerstone of the Confederacy (1861), w: Voices of Freedom. A Documentary History, red. Eric Foner, t. I, New York-London: W. W. Norton \& Company 2011. George Fitzhugh and the Proslavery Argument (1854), w: Voices of Freedom. A Documentary History, red. E. Foner, t. I, New York-London: W. W. Norton \& Company, 2011.

South Carolina Ordinance of Secession, w: Voices of Freedom. A Documentary History, red. E. Foner, t. I, New York-London: W. W. Norton \& Company 2011.

\footnotetext{
${ }^{72}$ Początkowo jedynie skrajne skrzydło Partii Republikańskiej (tzw. czarni Republikanie) opowiadało się za natychmiastową emancypacją wszystkich niewolników, wbrew jednak obiegowej opinii ówczesny program partii zakładał jedynie zastopowanie ekspansji niewolnictwa na nowe terytoria. Natomiast tam, gdzie niewolnictwo już funkcjonowało, nie miało być ono w żaden sposób ograniczane przez rząd federalny.

${ }^{73}$ M. Grimsley, “A Very Long Shadow”, s. 238-239; J.M. MCPherson, Marching Toward Freedom. Blacks in the Civil War 1861-1865, b.m.w. 1994, s. 91-96; TENŻE, The Negro's Civil War. How American Negroes Felt and Acted During the War for the Union, New York 1965, s. 193-203; G.J.W. URwin, “We Cannot Treat Negroes ... as Prisoners of War”, s. 139-140.
} 
Supplement to the Official Records of the Union and Confederate Armies, cz. 1, t. VI, cz. 2, t. LXXVII-LXXVIII, Wilmington: Broadfoot Publishing Company 1996-1998.

The Constitution of the Confederate States of America, w: Journal of the Congress of the Confederate States of America, 1861-1865, t. I, Washington: Government Printing Office 1904.

The Lincoln-Douglas Debates (1858), w: Voices of Freedom. A Documentary History, red. Eric Foner, t. I, New York-London: W. W. Norton \& Company 2011.

The War of the Rebellion: A Compilation of the Official Records of the Union and Confederate Armies, seria 1, t. XXXIII, XXXV, cz. 1, XL, cz. 1, seria 2, t. VII, Washington: Government Printing Office 1891-1899.

The Works of John C. Calhoun, t. II-IV, New York: D. Appleton and Company, 346 \& 348 Broadway, 1854.

Tochman Gaspard, Dr. Tochman's Letter to the Polish Democratic Societies, „Southern Literary Messenger. A magazine devoted to literature, science and art" 34 (1862), nr 5.

OPRACOWANIA

BAtes Samuel P., History of Pennsylvania Volunteers, 1861-5, t. V, Harrisburg: B. Singerly, State Printer 1871.

BernARD George S., War Talks of Confederate Veterans, Petersburg: Fenn \& Owen, Publishers 1892.

BurChard Peter, One Gallant Rush. Robert Gould Shaw and His Brave Black Regiment, New York: St. Martin's Press 1989.

COLES David J., "Shooting Niggers Sir". Confederate Mistreatment of Union Black Soldiers at the Battle of Olustee, w: Black Flag Over Dixie. Racial Atrocities and Reprisals in the Civil War, Gregory J. W. Urwin, Carbondale: Southern Illinois University Press 2004.

Connish DudleyT., The Sable Arm. Black Troops in the Union Army, 1861-1865, Lawrence: University of Kansas Press 1987.

DAy William A., A True History of Company I, 49th Regiment, North Carolina Troops in the Great Civil War between the North and South, Newton: Enterprise Job Office 1893.

Derengowski Piotr, Polacy w wojnie secesyjnej 1861-1865, Oświęcim: Napoleon V 2015.

Derengowski Piotr, The Polish Voice on Slaves and Slavery in the United States in MidNineteenth Century, w: East Central Europe in Exile, t. II, red. Anna Mazurkiewicz, Newcastle upon Tyne: Cambridge Scholar Publishing 2013.

DobAK William A., Freedom by the Sword. The U.S. Colored Troops, 1862-1867, Washington: Center of Military History United States Army 2011.

DunCAn Russel, Where Death and Glory Meet. Colonel Robert Gould Shaw and the 54th Massachusetts Infantry, Athens: University of Georgia Press 1999.

Emilio Luis F., History of the Fifty-Fourth Regiment of Massachusetts Infantry, 1863-1865, Boston: The Boston Book Company 1891.

FONER Eric, Give me Liberty! An American History, t. I-II, New York-London: W. W. Norton \& Company 2012.

FONER Eric, The Fiery Trial. Abraham Lincoln and American Slavery, New York-London: W. W. Norton \& Company 2010.

Grimsley Mark, "A Very Long Shadow”. Race, Atrocity, and the American Civil War, w: Black Flag Over Dixie. Racial Atrocities and Reprisals in the Civil War, red. G.J.W. Urwin, Carbondale: Southern Illinois University Press 2004.

Hargrove Hondon B., Black Union Soldiers in the Civil War, Jefferson-London: McFarland \& Company, Inc. Publishers 2003. 
Jordan Jr. Weymouth T., Thomas Gerald W., Massacre at Plymouth April 20, 1864, w: Black Flag Over Dixie. Racial Atrocities and Reprisals in the Civil War, red. G.J.W. Urwin, Carbondale: Southern Illinois University Press 2004.

KOPALIŃSKI Władysław, Stownik wyrazów obcych i zwrotów obcojęzycznych z almanachem, Warszawa: Świat Książki 2000.

MCPherson James M., Marching Toward Freedom. Blacks in the Civil War 1861-1865, Facts On File An Infobase Holdings Company 1994.

McPherson James M., The Negro's Civil War. How American Negroes Felt and Acted During the War for the Union, New York: Pantheon Books A Division of Random House 1965.

MichaŁEK Krzysztof, Dyplomaci i okręty. Z dziejów polityki zagranicznej Skonfederowanych Stanów Ameryki, Warszawa: PWN 1987.

PHILlips B.F., Wilcox's Alabamians in Virginia, „Confederate Veteran” 15 (1907), nr 11.

SŁoŃSKi Adam, Pogląd na Stany Zjednoczone Pótnocnej Ameryki, oraz na wojnę toczaca się obecnie w tym kraju, i przyczyny, które sa głównym jej powodem, Warszawa: Drukarnia Gazety Polskiej 1864.

Suderow Bryce A., The Battle of the Crater. The Civil War's Worst Massacre, w: The Black Flag Over Dixie. Racial Atrocities and Reprisals in the Civil War, red. G.J.W. Urwin, Carbondale: Southern Illinois University Press 2004.

Trudeau Noah A., Like Men of War. Black Troops in the Civil War 1862-1865, Boston-New York-Toronto-London: Southern Illinois University Press 1998.

URwIN Gregory J.W., "We Cannot Treat Negroes ... as Prisoners of War". Racial Atrocities and Reprisals in Civil War Arkansas, w: Black Flag Over Dixie. Racial Atrocities and Reprisals in the Civil War, red. G.J.W. Urwin, Carbondale: Southern Illinois University Press 2004.

URwIN Gregory J.W., Introduction. Warfare, Race, and the Civil War in American Memory, w: Black Flag Over Dixie. Racial Atrocities and Reprisals in the Civil War, red. G.J.W. Urwin, Carbondale: Southern Illinois University Press 2004.

WARNer Ezra J., Generals in Blue. Lives of the Union Commanders, Baton Rouge: LSU Press 1964.

\section{OKRUCIEŃSTWA WOJNY CZY PRZEJAW RASIZMU? PRZYPADKI ZNĘCANIA SIĘ NAD JEŃCAMI Z U.S. COLORED TROOPS (USCT) \\ NA WSCHODNIM TEATRZE DZIAŁAŃ WOJENNYCH WOJNY SECESYJNEJ - WYBRANE PRZYKŁADY}

$$
\text { Streszczenie }
$$

Wojna secesyjna nie bez powodu jest uważana za przełomowy konflikt w historii USA. Jednym $z$ takich powodów jest masowy udział Afroamerykanów, którzy po raz pierwszy od czasów wojny o niepodległość Stanów Zjednoczonych mogli służyć w armii (łącznie ok. 180 tys.). Choć wiele oddziałów U.S. Colored Troops nie było jednostkami frontowymi, to jednak część wojsk kolorowych brała czynny udział w operacjach wojskowych. Konsekwencją tego faktu było zaistnienie kwestii czarnoskórych jeńców. Oczywiście w tym wypadku warunkiem koniecznym było wzięcie ich do niewoli przez oddziały Południa. Niestety znacznie częściej zdarzały się przypadki znęcania się czy wręcz bestialskiego mordowania jeńców z U.S. Colored Troops (np. Olustee - 20 lutego 1864 r., Plymouth - 20 kwietnia 1864 r. itp.). Czy takie zachowanie żołnierzy konfederackich mieściło się w szeroko pojętych okrucieństwach wojny, rozumianych jako chęć wzięcia odwetu na oddziałach wroga, który plądruje ojczystą ziemię, chęć pomszczenia bliskich 
lub przyjaciół, którzy zginęli od kul przeciwnika itd. Czy jest to problem głębszy, mający swoje uwarunkowania w kulturze Południa, którego podstawą ideową było istnienie tzw. demokracji panów (Herrenvolk democracy), głęboko zakorzenione przekonanie o wyższości rasy białej nad czarną (nieobce także na Północy), które znalazło swoje odzwierciedlenie nie tylko w przemowach polityków Południa, a później Skonfederowanych Stanów Ameryki, ale także w konstytucji tego kraju.

Slowa kluczowe: Afroamerykanie; okrucieństwa wojny; rasizm; wojna secesyjna; zbrodnie wojenne.

\author{
ATROCITIES OF WAR OR MANIFESTATION OF RACISM? \\ MISTREATMENT OF POWS FROM THE U.S. COLORED TROOPS (USCT) \\ IN THE EASTERN THEATRE DURING THE CIVIL WAR: SELECTED EXAMPLES
}

\title{
S u m mary
}

It is not without reason that the Civil War is considered to be a turning point in US history. One of them was the mass participation of African Americans, who, for the first time since the War of Independence, were allowed to serve in the army (total ca.180,000). Even though many U.S. Colored Troops were not frontal units, nevertheless some of them did actively participate in military operations. As a consequence an issue of black prisoners of war occurred. Obviously, in this case, they had to be captured by Southern troops first. Unfortunately, much oftener, there were instances of mistreatment or even brutal slaughter of POWs from U.S. Colored Troops (i.e. Olustee - Feb. 20, 1864; Plymouth - April 20, 1864, etc.). Did such behavior of Confederate soldiers fit in in wide definition of war atrocities, understood as a will to take revenge at enemy's troops, which plunder mother country, to avenge your family and friends, killed by the enemy, etc. Or it is a much deeper problem, having its conditioning in the culture of the South, whose ideological foundation was existence of so called Herrenvolk democracy, deeply rooted belief about superiority of white race over black (known also in the North), which was reflected not only in speeches of Southern, and later Confederate, politicians but also in the Constitution of the Confederate States of America.

Key words: African Americans; Civil War; racism; war atrocities; war crimes. 